\title{
Effect of adding the Limiting Amino Acids to Low - Crude Protein Diets on Performance of Broiler Chicks.
}

\author{
Mohammed A. Abd El-Fatah Mohammed'; Mohamed M.Abdella1; \\ Gamal Aly El-din El- sayaad ${ }^{1}$; Abdel-Khalek, A.M. ${ }^{2}$ \\ ${ }^{1}$ Animal production department, Faculty of Agriculture, Benha University, Egypt \\ ${ }^{2}$ Poultry Nutrition Department, Animal Production Research Institute, ARC, Egypt. \\ Corresponding author: mmnegm176@gmail.com
}

\begin{abstract}
This study was conducted to study the effect of decreasing the dietary crude protein level while supplementing the essential amino acids on growth performance, carcass, some blood constitutes of broiler chicks. An experiment was done using 252 one day-old broiler chicks Arbor-acres, randomly allotted to seven dietary treatment groups; the first group positive control with optimum CP level (PC), the second group negative control (NC) low 3 points than requirements, and groups 3 up 7 were fed the NC diet but supplemented incrementally with the essential amino acids; lysine, lysine+ methionine, lysine+ methionine+ tryptophan, lysine+ methionine+ tryptophan +threonine and lysine+ methionine+ tryptophan+ threonine+ valine, respectively to cover the dietary requirements for each amino acid during starter, grower and finisher periods. Results show that there were no significant differences between treatments $(\mathrm{P}=0.242)$ on starter live weight. For grower period the control group with optimum CP \% level, followed by low CP \% diet supplemented with all amino acids had significantly the highest live body weight compared with the low $\mathrm{CP}$ group without supplemental amino acids $(\mathrm{P}=0.006)$. The gains in body weight were found to be significant during grower and finisher phases the highest values were observed in the positive control and low CP supplemental with all AA diets. The same two treatments the best FCR for the overall experimental period compared to the other treatments. Carcass traits were not significantly affected by dietry treatments. Plasma total protein $(\mathrm{P}=0.034)$, albumin $(\mathrm{P}=0.002)$, and triglycerides $(\mathrm{P}=0.002)$, were significantly affected by dietary treatments. The lowest feed cost per kg live weight gain of chickens were found in the experimental group (T7) containing all amino acids supplemented to the low CP diets. It could be recommended to decrease the dietary $\mathrm{CP}$ level of broiler chicks by 3 points without affecting the growth performance up on supplementing the essential AA.
\end{abstract}

Key words: crude protein (CP), positive control (PC), performance, dressing

\section{Introduction}

Dietary protein is one of the most important factors affecting poultry production. Our information about feeding of amino acids has been progressed in two or three recent decades. This progress is undoubtedly due to the production of synthetic amino acids. Effects of supplementary amino acid in reducing protein intake, feed consumption and environmental pollution via reduce pollutants excretion (ammonia nitrogen) by farm animals, is main reasons for using of these supplements (Aletor et al., 2000). Lowering dietary protein levels and use of synthetic amino acids, while reduce cost of diet, have reduced environmental pollution of nitrogen (Bregendahl et al., 2002).

Methionine (Met.) and lysine (Lys.) are the major amino acid (AA) that are supplemented in poultry diets mostly due to their high production demand in the commercial markets, however, threonine (Thr.) and tryptophan (Trp) are also used in the poultry feed industry, but their volume of use is not as high as Met. and Lys. (Malveda et al., 2006). Also commercial production of valine (Val.) became available latter (Waguespack et al., 2009). The efficiency of amino acid utilization is best when all amino acids are at or slightly below, but not above, their need for protein accretion and maintenance. In addition, formulating diets that meet, but do not exceed, amino acid needs also results in less nitrogen excretion. Formulating broiler diets using the economically feasible commercial amino acid supplements results in diets marginally reduced in crude protein that support equal broiler growth to diets containing higher crude protein and excessive amino acids (Kidd $\boldsymbol{e t}$ al., 2002).

Decreasing CP levels lower than requirements significantly decreased body weight gain and increased the feed conversion ratio. Adding the essential limiting amino acids to the low CP diets significantly improved the performance but did not completely overcome the adverse effects of the low CP diets (Waldroup et al., 2005). On the other hand (Abdel Maksoud et al., 2010) found that birds fed the low-protein diets supplemented with essential amino acids showed significantly higher live body weight and better feed conversion ratio than optimum CP diet. Abbasi et al., (2014) recorded the effects of different dietary CP and Thr. levels on the performance indicate that it is possible to reduce dietary CP level up to $10 \%$ after the starter period without any detrimental impact on growth performance. The supplementation of limiting amino acids (LAA) in low CP diet could avoid performance reduction due to low $\mathrm{CP}$ content of 
diet and simultaneously decrease nitrogen excretion in broiler chickens (Koreleski and Swiatkiewicz., 2008). Dietary CP led to reduces the heat production and water consumption which help in lowering moisture content of litter. reduction in $\mathrm{CP}$ level in broiler diet can also allow for the use of a greater variety of feedstuffs which can be valuable in itself as a method to increase flexibility in the choice of locally available feedstuffs ( Alleman and Leclercq, 2007).

\section{Materials and Methods}

The experimental work of the present study was carried out at private poultry farm at Moshtohor, El Qalubyia Governorate, Egypt, during the period from $19^{\text {th }}$ December to $24^{\text {th }}$ of January 2018. It was aimed to evaluate the effect of dietary supplementation of essential amino acids to low crude protein diets(less $3 \%$ than requirements) on performance of broiler chicken.

Table 1. Proportion of ingredients and calculated nutrient composition of starter diet (0-10 days of age

\begin{tabular}{|c|c|c|c|c|c|c|c|}
\hline Ingredient & $\begin{array}{l}\text { Positive } \\
\text { control }\end{array}$ & $\begin{array}{c}\text { Negative } \\
\text { control }\end{array}$ & $\begin{array}{l}\text { Negative } \\
\text { +Lysine }\end{array}$ & $\begin{array}{l}\text { Neg.+Lys } \\
\text { +Meth }\end{array}$ & $\begin{array}{c}\text { Neg.+Lys+Me } \\
\text { th }+ \\
\text { Trept }\end{array}$ & $\begin{array}{c}\text { Neg.+Lys+Me } \\
\text { th+Cys+ } \\
\text { Trept+Thr }\end{array}$ & $\begin{array}{c}\text { Neg.+Lys+Me } \\
\text { th++ } \\
\text { Trept+Thr } \\
\text { +Valine }\end{array}$ \\
\hline yellow corn & 54.85 & 64.25 & 64.5 & 65.1 & 65.21 & 65.3 & 65.6 \\
\hline Soybean meal $44 \%$ & 31.0 & 24 & 24 & 22.7 & 22.7 & 22.8 & 22.5 \\
\hline Corn Gluten $60 \%$ & 7.6 & 7.5 & 6.5 & 7 & 6.96 & 6.56 & 6.35 \\
\hline Soya Oil & 2.0 & 0.5 & 0.5 & 0.25 & 0.25 & 0.25 & 0.25 \\
\hline Calcium Phosphate & 1.75 & 1.8 & 1.8 & 1.85 & 1.24 & 1.25 & 1.25 \\
\hline Limestone & 1.25 & 1.25 & 1.25 & 1.25 & 1.85 & 1.85 & 1.84 \\
\hline L-lysine & 0.4 & & 0.65 & 0.69 & 0.69 & 0.69 & 0.71 \\
\hline DL-Methionine & 0.26 & - & - & 0.36 & 0.36 & 0.37 & 0.38 \\
\hline L.treptophan & - & - & - & - & 0.04 & 0.04 & 0.04 \\
\hline L-Threonine & 0.06 & - & - & - & - & 0.19 & 0.2 \\
\hline L-valine & 0.03 & - & - & - & - & - & 0.19 \\
\hline $\begin{array}{l}\text { Vitamin-Mineral } \\
\text { premix }\end{array}$ & 0.3 & 0.3 & 0.3 & 0.3 & 0.3 & 0.3 & 0.3 \\
\hline $\mathrm{NaCl}$ & 0.3 & 0.3 & 0.3 & 0.3 & 0.3 & 0.3 & 0.3 \\
\hline Anti-toxin & 0.1 & 0.1 & 0.1 & 0.1 & 0.1 & 0.1 & 0.1 \\
\hline
\end{tabular}

Experimental diets: Chicks were allocated to one of the following dietary's ever treatments (36 chicks/treatment-with 3 replicates):

Group (1): catalogue recommendation (optimum CP and ME level).

Group (2): $-3 \%$ CP.

Group (3): $-3 \% \mathrm{CP}+$ optimum lysine.

Group (4): $-3 \% \mathrm{CP}+$ optimum lysine +optimum methionine.

Group (5): $-3 \% \mathrm{CP}+$ optimum lysine + optimum methionine + optimum tryptophan.

Group (6): $-3 \% \mathrm{CP}+$ optimum lysine + optimum methionine + optimum tryptophan + optimum threonine.

Group (7): $-3 \% \mathrm{CP}+$ optimum lysine + optimum methionine + optimum tryptophan + optimum threonine + optimum valine.

Calculated Chemical analysis \%:

\begin{tabular}{lccccccc}
\hline $\mathrm{CP}(\%)$ & 23.05 & 20.0 & 20.05 & 20.07 & 20.08 & 20.09 & 20.08 \\
\hline $\mathrm{ME}(\mathrm{Kcal} / \mathrm{kg})$ & 3003 & 3003 & 3001 & 3004 & 3004 & 3002 & 3006 \\
$\mathrm{Ca}(\%)$ & 0.96 & 0.96 & 0.96 & 0.96 & 0.96 & 0.96 & 0.96 \\
Avail Ph (\%) & 0.48 & 0.48 & 0.48 & 0.48 & 0.48 & 0.48 & 0.48 \\
L-lysine (\%) & 1.44 & 0.94 & 1.44 & 1.44 & 1.44 & 1.44 & 1.44 \\
DLMethionine(\%) & 1.08 & 0.76 & 0.73 & 1.08 & 1.08 & 1.08 & 1.08 \\
L.treptophan(\%) & 0.23 & 0.20 & 0.20 & 0.19 & 0.23 & 0.23 & 0.23 \\
L-Threonine (\%) & 0.97 & 0.82 & 0.79 & 0.78 & 0.78 & 0.97 & 0.97 \\
L-valine(\%) & 1.1 & 0.96 & 0.94 & 0.92 & 0.92 & 0.92 & 1.1 \\
\hline
\end{tabular}

Each3.0 Kg of the Vit. And Min.premix contains: **Additives it. A-14mIU, D3-5.0 mIU, E-75000mg, B1-3000mg, B28000mg, B6-4000mg, B12-16mg, Niacin-70000mg, Calcium-D-Pantothenc acid 20000mg, Biotin-150mg, Folic Acid-
Birds and their management: A total number of 252, day-old unsexed Arbor Acres broiler chicks were in this study. Chicks were kept under similar separate pens with 12 birds/m2 stoking density until the end of the experiment. Wood shaving was used at depth as a litter. Floor brooders with gas heaters brooding chicks. Brooding temperature was maintained at $33^{\circ} \mathrm{C}$ the first 5 days of chicks age then 列 fed starter diet at the first ten days of age then replaced with grower diet during 11-24day of age, finally diets were used from 25- to the end of the formulated according to the recommended requirements of strain. 
2000mg and Vit-K-4000mg and antioxidant, $10 \mathrm{~g}$, and complete to $3.0 \mathrm{~kg}$ by calcium carbonate. Trace mineral mixture:Fe$80000 \mathrm{mg}$, I-1000mg, Cu-8000mg, Mn-100000mg, Zn-80000mg, Se-150mg,Mo-1000mg:

Table 2. Proportion of ingredients and calculated nutrient composition of growing diets (11-24 days) of age.

\begin{tabular}{|c|c|c|c|c|c|c|c|}
\hline Ingredient & $\begin{array}{l}\text { Positive } \\
\text { Control }\end{array}$ & $\begin{array}{l}\text { Negative } \\
\text { control }\end{array}$ & $\begin{array}{l}\text { Negative } \\
+ \text { Lysine }\end{array}$ & $\begin{array}{l}\text { Neg.+Ly } \\
\text { S } \\
+ \text { Meth }\end{array}$ & $\begin{array}{l}\text { Neg.+Ly } \\
\text { S+Meth+ } \\
\text { Treptophan }\end{array}$ & $\begin{array}{l}\text { Neg.+Ly } \\
\text { s+ } \\
\text { Meth+ } \\
\text { Treptoph } \\
\text { an+Threo } \\
\text { nin }\end{array}$ & $\begin{array}{l}\text { Neg.+Ly } \\
\text { s+ } \\
\text { Meth+ } \\
\text { Treptoph } \\
\text { an + } \\
\text { Threonin } \\
\text { +Valine }\end{array}$ \\
\hline yellow corn & 56.86 & 64.6 & 65.0 & 65.0 & 65.0 & 65.0 & 65.2 \\
\hline Soybean meal $44 \%$ & 28.8 & 24.7 & 24.3 & 24.3 & 24.3 & 24.41 & 24.3 \\
\hline Corn Gluten $60 \%$ & 6.7 & 4.5 & 4.0 & 3.65 & 3.65 & 3.3 & 3.05 \\
\hline Soya Oil & 3.4 & 2.65 & 2.6 & 2.6 & 2.6 & 2.65 & 2.65 \\
\hline DiCa.+ Phosphate & 1.58 & 1.60 & 1.65 & 1.65 & 1.65 & 1.65 & 1.65 \\
\hline Limestone & 1.15 & 1.15 & 1.16 & 1.16 & 1.16 & 1.16 & 1.16 \\
\hline L-lysine & 0.31 & - & 0.49 & 0.49 & 0.49 & 0.49 & 0.49 \\
\hline DL-Methionine & 0.24 & - & - & 0.35 & 0.36 & 0.36 & 0.37 \\
\hline L.treptophan & - & - & - & - & 0.03 & 0.03 & 0.03 \\
\hline L-Thrionine & 0.2 & - & - & - & - & 0.15 & 0.15 \\
\hline L-valine & - & - & - & - & - & - & 0.15 \\
\hline Vit-Min premix & 0.3 & 0.3 & 0.3 & 0.3 & 0.3 & 0.3 & 0.3 \\
\hline $\mathrm{NaCl}$ & 0.4 & 0.4 & 0.4 & 0.4 & 0.4 & 0.4 & 0.4 \\
\hline Anti-toxin & 0.1 & 0.1 & 0.1 & 0.1 & 0.1 & 0.1 & 0.1 \\
\hline
\end{tabular}

Calculated Chemical analysis of the grower diets:

\begin{tabular}{llllllll}
\hline $\mathrm{CP}(\%)$ & 21.54 & 18.55 & 18.56 & 18.56 & 18.57 & 18.58 & 18.55 \\
\hline $\mathrm{ME}(\mathrm{Kcal} / \mathrm{kg})$ & 3104 & 3103 & 3103 & 3102 & 3102 & 3103 & 3103 \\
$\mathrm{Ca}(\%)$ & 0.88 & 0.88 & 0.89 & 0.89 & 0.89 & 0.89 & 0.89 \\
Avail Ph (\%) & 0.44 & 0.44 & 0.44 & 0.44 & 0.44 & 0.44 & 0.44 \\
-lysine (\%) & 1.29 & 0.93 & 1.29 & 1.29 & 1.29 & 1.29 & 1.29 \\
Methionine (\%) & 1.0 & 0.68 & 0.67 & 1.0 & 1.0 & 1.0 & 1.0 \\
treptophan(\%) & 0.22 & 0.2 & 0.19 & 0.19 & 0.22 & 0.22 & 0.22 \\
Threonine (\%) & 0.88 & 0.76 & 0.75 & 0.74 & 0.74 & 0.88 & 0.88 \\
valine $(\%)$ & 1.01 & 0.89 & 0.87 & 0.86 & 0.86 & 0.86 & 1.0 \\
\hline
\end{tabular}

Each3.0 Kg of the Vit. And Min. premix contains: **Additives it. A-14mIU, D3-5.0 mIU, E-75000mg, B1-3000mg, B2-8000mg, B6-4000mg, B12-16mg, Niacin-70000mg, Calcium-D-Pantothenc acid 20000mg, Biotin-150mg, Folic Acid-2000mg and Vit-K-4000mg and antioxidant, $10 \mathrm{~g}$, and complete to $3.0 \mathrm{~kg}$ by calcium carbonate. Trace mineral mixture:Fe- $80000 \mathrm{mg}, \mathrm{I}-1000 \mathrm{mg}, \mathrm{Cu}-8000 \mathrm{mg}, \mathrm{Mn}-100000 \mathrm{mg}$, Zn-80000mg, Se-150mg,Mo-1000mg:

Table 3. Proportion of ingredients and calculated nutrient composition of finisher diets (25-37 days) of age.

\begin{tabular}{|c|c|c|c|c|c|c|c|}
\hline Ingredient & $\begin{array}{l}\text { Positive } \\
\text { Control }\end{array}$ & $\begin{array}{l}\text { Negative } \\
\text { control }\end{array}$ & $\begin{array}{l}\text { Negative } \\
\text { +Lysine }\end{array}$ & $\begin{array}{l}\text { Neg.+Lys } \\
+ \text { Meth }\end{array}$ & $\begin{array}{l}\text { Neg.+Lys+Me } \\
\text { th++ } \\
\text { Treptophan+T } \\
\text { hreonin }\end{array}$ & $\begin{array}{l}\text { Neg.+Lys+ } \\
\text { Met }+ \\
\text { Treptophan }\end{array}$ & $\begin{array}{l}\text { Neg.+Lys } \\
+ \text { Met+ } \\
\text { Trep+ } \\
\text { Thre } \\
+ \text { Valine }\end{array}$ \\
\hline yellow corn & 57.3 & 65.7 & 66.57 & 66.8 & 66.87 & 66.80 & 67.28 \\
\hline Soybean meal & 31.5 & 25.9 & 25.0 & 24.5 & 24.3 & 24.36 & 23.80 \\
\hline Corn Gluten60 & 1.7 & 0.15 & 0.1 & 0.1 & 0.1 & 0.1 & 0.1 \\
\hline Soya Oil & 6.0 & 5.0 & 4.75 & 4.65 & 4.65 & 4.65 & 4.55 \\
\hline DiCa. Phosphate & 1.33 & 1.41 & 1.41 & 1.41 & 1.41 & 1.41 & 1.41 \\
\hline Limestone & 1.01 & 1.04 & 1.04 & 1.04 & 1.04 & 1.04 & 1.04 \\
\hline L-lysine & 0.1 & - & 0.33 & 0.35 & 0.36 & 0.36 & 0.38 \\
\hline DL-Methionine & 0.25 & - & - & 0.35 & 0.36 & 0.36 & 0.36 \\
\hline L.treptophan & - & - & - & - & 0.01 & 0.01 & 0.01 \\
\hline L-Thrionine & - & - & - & - & 0.11 & - & 0.12 \\
\hline L-valine & - & - & - & - & - & - & 0.14 \\
\hline Vit-Min premix & 0.3 & 0.3 & 0.3 & 0.3 & 0.3 & 0.3 & 0.3 \\
\hline $\mathrm{NaCl}$ & 0.4 & 0.4 & 0.4 & 0.4 & 0.4 & 0.4 & 0.4 \\
\hline Anti-toxin & 0.1 & 0.1 & 0.1 & 0.1 & 0.1 & 0.1 & 0.1 \\
\hline
\end{tabular}


Calculated Chemical analysis of the finisher diets:

\begin{tabular}{llllllll}
\hline $\mathrm{CP}(\%)$ & 19.53 & 16.54 & 16.5 & 16.5 & 16.54 & 16.54 & 16.53 \\
\hline $\mathrm{ME}(\mathrm{Kcal} / \mathrm{kg})$ & 3200 & 3202 & 3201 & 3201 & 3203 & 3204 & 3205 \\
$\mathrm{Ca}(\%)$ & 0.79 & 0.79 & 0.79 & 0.79 & 0.79 & 0.79 & 0.79 \\
$\mathrm{Avail} \mathrm{Ph}(\%)$ & 0.395 & 0.397 & 0.396 & 0.395 & 0.395 & 0.395 & 0.395 \\
lysine (\%) & 1.16 & 0.92 & 1.16 & 1.16 & 1.16 & 1.16 & 1.16 \\
methionine (\%) & 0.91 & 0.58 & 0.57 & 0.91 & 0.91 & 0.91 & 0.91 \\
treptophan(\%) & 0.22 & 0.19 & 0.19 & 0.18 & 0.18 & 0.19 & 0.19 \\
threonine (\%) & 0.8 & 0.69 & 0.68 & 0.67 & 0.78 & 0.78 & 0.78 \\
valine(\%) & 0.92 & 0.80 & 0.79 & 0.78 & 0.77 & 0.77 & 0.9 \\
\hline
\end{tabular}

Each3.0 Kg of the Vit. And Min.premix contains: **Additives it. A-14mIU, D3-5.0 mIU, E-75000mg, B1-3000mg, B2-8000mg, B6-4000mg, B12-16mg, Niacin-70000mg, Calcium-D-Pantothenc acid 20000mg, Biotin-150mg, Folic Acid-2000mg and Vit-K-4000mg and antioxidant, $10 \mathrm{~g}$, and complete to $3.0 \mathrm{~kg}$ by calcium carbonate.Trace mineral mixture:Fe-80000mg, I-1000mg, Cu-8000mg, Mn-100000mg, $\mathrm{Zn}-80000 \mathrm{mg}$, Se-150mg,Mo-1000mg:

\section{Measurements: Growth performance:}

Live Body weight, the live weights of day-old chicks were recorded on arrival and thereafter at weekly intervals. From these data, average weekly live weights and average weekly gain in weights were calculated for each group. Chicks were individually weight to the nearest $(\mathrm{g})$ at hatch at the finally starter, grower, finish period of birds age

Feed intake, the records maintained for daily feed consumption were used to calculate average weekly feed consumption.

Feed conversion ratio of various groups were also calculated using gain in weights and feed consumption of these groups. The daily record of mortality, if any, during the experimental period was also maintained.

Carcass characteristics, Carcass traits as influenced by the feeding of essential amino acids in terms of dressing percentage, abdominal fat, oregan metric was evaluated. Four birds per treatment, randomized, making a total of 28 birds were selected randomly at the end of the feeding experiment.

plasma biochemical parameters, the blood samples for plasma biochemical analyses were collected from 4 birds in each treatment at the end of the growth of experiment. The blood was collected up on slaughtering in heparinized tubes and subject to centrifugation at $3000 \mathrm{rpm}$ for 10 minutes. The plasma samples were analyzed for total protein (Gornallet al.,1949), albumin(Doumaset al., 1971), triglyceridesand glucose(Soloni.,1971)after finishing. Economic Efficiency, The economics of broiler production was calculated at the end of experiment considering feed cost as the only variable. The feed cost per kilogram was calculated by considering the prevailing prices of the feed ingredients were the price of one kilogram live weight in local market was $25 \mathrm{LE}$ during the experimental and calculated as follows: Economic Efficiency Ggain:

EEG $=100 \times[$ [sale price per total gain - total feed cost) / total feed cost]

\section{Statically analysis:}

Data collected were subjected to General Linear Model procedure of SAS users guide (SAS, 2001).Differences between means were tested using Duncans multiple range tests (Duncans,1955).One way analysis model was applied for experiment $Y_{i j}=$
$\mu+T_{i}+e_{i j}$ where $Y_{i j}=$ an observation, $\mu=$ overall mean $_{i}=$ Effect of $I^{\text {th }}$ treatments $(i=1, \ldots, 5) \cdot \mathrm{e}_{\mathrm{i}}=$ Experimental error.

\section{Results and Discussion}

Growth Performance: Live Body Weight, results indicate the effect of dietary treatments on live body weight of chicken through different experimental periods are presented in Table (4).There was insignificant differences between treatment $(\mathrm{P}=0.242)$ on starter weight up to 11 days of age. For grower period up to 24 days of age the control group with optimum CP \% level, followed by low CP \% diet supplemented with all amino acids (Trt 7) had significantly the highest live body weight compared with the low $\mathrm{CP}$ group without supplemental amino acids $(P=0.006)$.The latter was not significantly differ from other low CP diet supplemented with A.A. (Trt 3 up to 6).Also, The optimum CP diet, followed by low $\mathrm{CP}+$ all A.A diet, then all A.A combination diet except that supplemented with lysine alone had significantly $(\mathrm{P}=0.002)$ higher final body weight than the negative control deprived from supplemental AA. Live Body weigh gain, data illustrated through different experimental periods are presented in Table (5) show the response of broilers to dietary treatments interims of live body weigh gain(LBWG).During starter phase, LBWG did not differ, significantly $(\mathrm{P}=0.231)$ between experimental groups .During grower period (11-24 days of age ) the optimum CP level supplemented with all A.A gave the highest gains $(\mathrm{P}=0.008)$, followed by other A.A supplemented groups but not significantly differ from the negative control group. During finisher phase (25-37 of age ), the low CP level with lysine + methionine the low CP supplemented with all A.A except valine, followed by low CP level supplemented with all A.A the positive control group with optimum CP level (all nutrient meet the requirements of the strain), followed by the group with low CP level supplemented with all A.A showed significantly $(\mathrm{P}=0.001)$ higher LBWG estimated by 19.2 and $16.99 \%$, respectively, over that obtained by the negative control group .Also, supplementing the negative control diet with A.A, resulted in better total gains compared to chicks had no access to such supplementation. 
Feed intake (FI), data illustrated through different experimental periods are presented in Table (6) show the effect of dietary treatments without holding significant difference, except for FI during finisher period $(\mathrm{P}=0.033)$, The studied treatments did not significantly affect FI during starter, grower, and overall period. Broiler chicks received low protein diet supplemented by lysine + methionine followed by those had access to the first four limiting A.A (without supplemental valine) showed respectively, the highest FI during finisher period compared with the rest of the treatments including the controls.

Feed conversion ratio(FCR), data in Table (7) reveal that the best result $\mathrm{s}$ were recorded with broiler groups feed low CP diet supplemented with all A.A (Trt.7) ,followed by the control with optimum $\mathrm{CP}$ diet, then the low CP supplemented with the first four A.A. The improvements in FCR in those treatments over the control with low CP alone (Trt.2) were estimated by
16.5, 14.2 and $11.8 \%$, respectively for the total experimental term.

Carcass characteristics, data in Table (8) reveal that all studied Carcass variables including Dressing $(\mathrm{P}=0.563)$ and carcass $(\mathrm{P}=0.559)$ total giblets $(\mathrm{P}=0.266)$ and abdominal fat $(\mathrm{P}=0.518)$ percentages were not significantly affected by dietry treatments under evaluation. However, dressing and carcass percentages were the highest with the chicks had a sufficient dietary CP level. Also, it is remarkable that the broilers group that was fed the control with low $\mathrm{CP}$ diet and the broiler group fed the low CP diet supplemented with all A.A without valine supplementation (Trt.6) had the lowest abdominal fat accumulation. The carcass characteristics as affected by the supplementation of A.A by reducing the dietary $\mathrm{CP}$ levels on the performance of broilers are shown in Table (15).

Table 4. Effect of supplementation amino acid to low-crude protein on body weight of birds (g/bird).

\begin{tabular}{lllll}
\hline Period Groups & Initial Period & Starter Period & Grower Period & Finisher Period \\
Positive control & 56.3 & 212 & $1198^{\mathrm{a}}$ & $1932^{\mathrm{a}}$ \\
Neg. control & 56.1 & 197 & $1000^{\mathrm{c}}$ & $1631^{\mathrm{d}}$ \\
N.+ lysine & 56.3 & 199 & $1025^{\mathrm{bc}}$ & $1693^{\mathrm{d}}$ \\
Neg. + Lys + methionine & 56.4 & 195 & $1020^{\mathrm{bc}}$ & $1828^{\mathrm{b}}$ \\
Neg.+ Lys + Meth + Trept & 56.3 & 199 & $1038^{\mathrm{bc}}$ & $1772^{\mathrm{c}}$ \\
Neg.+ Lys + Meth + Treptn +Theri & 56.1 & 204 & $1083^{\mathrm{bc}}$ & $1871^{\mathrm{ab}}$ \\
N.+ Lys + Meth + Trept + Ther + Val & 55.9 & 221 & $1121^{\mathrm{b}}$ & $1896^{\mathrm{a}}$ \\
PSE & 0.27 & 7.54 & 31.2 & 37.75 \\
P & 0.926 & 0.242 & 0.006 & 0.001 \\
\hline a-d-c-d means have different superscripts in the same column are significantly differed. &
\end{tabular}

Table 5. Effect of supplementing amino acids to low-crude protein on body weight gain of birds $(\mathrm{g})$

\begin{tabular}{lllll}
\hline Group & starter & Grower & Finisher & Total \\
\hline Positive control & 156 & $986^{\mathrm{a}}$ & $734^{\mathrm{ab}}$ & $1876^{\mathrm{a}}$ \\
Negative control & 141 & $803 \mathrm{c}$ & $631^{\mathrm{c}}$ & $1574^{\mathrm{d}}$ \\
Neg.+lysine & 143 & $826^{\mathrm{bc}}$ & $668^{\mathrm{c}}$ & $1637^{\mathrm{d}}$ \\
Neg.+Lys+methionine & 139 & $825^{\mathrm{c}}$ & $807^{\mathrm{a}}$ & $1771^{\mathrm{b}}$ \\
Neg.+Lysine+Methe+Trep & 143 & $839^{\mathrm{bc}}$ & $734^{\mathrm{b}}$ & $1716^{\mathrm{c}}$ \\
Neg.+Lys+Meth+Trep+Ther & 148 & $879^{\mathrm{bc}}$ & $788^{\mathrm{a}}$ & $1815^{\mathrm{ab}}$ \\
N.+Lys+Meth+Trep+Ther+Val & 156 & $900^{\mathrm{ab}}$ & $755^{\mathrm{a}}$ & $1840^{\mathrm{a}}$ \\
PSE & 7.53 & 28.85 & 29.20 & 37.71 \\
P & 0.231 & 0.008 & 0.007 & 0.001 \\
a-b-c & & &
\end{tabular}

Table 6. Effect of supplementing amino acids to low-crude protein on feed intake of birds (g) during experimental periods.

\begin{tabular}{lllll}
\hline Groups & Starter & Grower & Finisher & Feed \\
\hline Positive control & 238 & 1340 & $1741^{\mathrm{b}}$ & 3309 \\
Neg. control & 215 & 1328 & $1743^{\mathrm{b}}$ & 3336 \\
Neg.+ lysine & 217 & 1308 & $1726^{\mathrm{b}}$ & 3251 \\
Neg.+ Lys + methionine & 205 & 1367 & $1927^{\mathrm{a}}$ & 3499 \\
Neg.+Llys +Meth+Trep & 234 & 1378 & $1674^{\mathrm{b}}$ & 3286 \\
N..+ Lys+ Methe+Trep+ Ther & 218 & 1362 & $1804^{\mathrm{bb}}$ & 3384 \\
N.+Lys+Meth+Trep+Ther+Val & 239 & 1356 & $1656^{\mathrm{b}}$ & 3251 \\
PSE & 9.68 & 42.7 & 50.93 & 75.42 \\
P & 0.157 & 0.573 & 0.033 & 0.256 \\
\hline
\end{tabular}

${ }^{\mathrm{a}-\mathrm{b}}$ means have different superscripts in the same column are significantly differed. 
Table 7. Effect of supplementing amino acids to low-crude protein on FCR during the experimental

\begin{tabular}{lllll}
\hline Group & Starter & Grower & Finisher & Total \\
\hline Possative control & 1.53 & 1.45 & $2.38^{\mathrm{bc}}$ & $1.82^{\mathrm{d}}$ \\
Neg. control & 1.53 & 1.66 & $2.84^{\mathrm{a}}$ & $2.12^{\mathrm{a}}$ \\
Neg.+lysine & 1.51 & 1.59 & $2.59^{\mathrm{b}}$ & $1.99^{\mathrm{b}}$ \\
Neg.+Lys+methionine & 1.47 & 1.66 & $2.39^{\mathrm{bc}}$ & $1.98^{\mathrm{b}}$ \\
Neg.+Lys+Meth+ Trep & 1.64 & 1.65 & $2.29^{\mathrm{c}}$ & $1.91^{\mathrm{b}}$ \\
Neg.+Lysi+Meth+ Trep+Ther & 1.47 & 1.55 & $2.30^{\mathrm{bc}}$ & $1.87^{\mathrm{cd}}$ \\
N.+Lys+Meth+Trep+Ther+Val & 1.46 & 1.51 & $2.15^{\mathrm{c}}$ & $1.77^{\mathrm{d}}$ \\
PSE & 0.05 & 0.07 & 0.11 & $0.04^{1}$ \\
P & 0.196 & 0.246 & 0.015 & 0.001 \\
\hline a-d-c-d means have different superscripts in the same column are significantly differed. & &
\end{tabular}

Table 8. Effect of supplementing amino acids to low-crude protein on the carcass characteristics and Organometry of the birds.

\begin{tabular}{lllll}
\hline Group & Dressing & Carcass & Total Giblets & Abdominal fat \\
\hline Positive control & 73.1 & 67.8 & 5.29 & 1.05 \\
Neg. control & 71.6 & 66.0 & 5.52 & 0.84 \\
Neg.+lysine & 71.5 & 65.8 & 5.58 & 1.06 \\
Neg.+Lys+methionine & 72.5 & 67.3 & 5.14 & 1.19 \\
Neg.+Lys+Meth+Trep & 71.5 & 66.2 & 5.17 & 1.15 \\
Neg.+Lys+Meth+Trep+Ther & 71.5 & 66.8 & 5.21 & 0.78 \\
N.+Lys +Meth+Trep +Ther+ Val & 72.9 & 67.3 & 5.55 & 1.10 \\
PSE & 0.80 & 0.84 & 0.28 & 0.14 \\
P & 0.563 & 0.559 & 0.266 & 0.518 \\
\hline
\end{tabular}

Table 9. Effect of supplemental amino acids on plasma parameters (mg/dl) of the birds.

\begin{tabular}{lllllll}
\hline Group & Total P. & Albumin & Globulin & A/G & Triglyceride & Glucose \\
\hline Positive control & $2.86^{\mathrm{ab}}$ & $1.18^{\mathrm{bc}}$ & 1.50 & 0.81 & $74.3^{\mathrm{b}}$ & 210 \\
Neg. control & $2.28^{\mathrm{b}}$ & $0.99^{\mathrm{d}}$ & 1.29 & 0.82 & $69.0^{\mathrm{b}}$ & 213 \\
Neg.+lysine & $2.38^{\mathrm{b}}$ & $1.03^{\mathrm{d}}$ & 1.35 & 0.76 & $98.8^{\mathrm{a}}$ & 206 \\
Neg.+Lys+methionine & $2.30^{\mathrm{b}}$ & $0.98^{\mathrm{d}}$ & 1.32 & 0.75 & $81.5^{\mathrm{b}}$ & 206 \\
Neg.+Lys+Meth+Trep & $2.50^{\mathrm{b}}$ & $1.11^{\mathrm{cd}}$ & 1.39 & 0.80 & $86.5^{\mathrm{ab}}$ & 213 \\
Neg.+Lys+Meth+Trep+Ther & $2.60^{\mathrm{ab}}$ & $1.22^{\mathrm{ab}}$ & 1.38 & 0.89 & $76.5^{\mathrm{b}}$ & 205 \\
N.+Lys+Meth+Trep+Ther+Val & $2.87^{\mathrm{a}}$ & $1.28^{\mathrm{a}}$ & 1.59 & 0.81 & $40.0^{\mathrm{c}}$ & 212 \\
PSE & 0.13 & 0.05 & 0.12 & 0.07 & 6.51 & 7.66 \\
P & 0.034 & 0.002 & 0.385 & 0.867 & 0.002 & 0.960 \\
\hline
\end{tabular}

${ }^{\mathrm{a}-\mathrm{d}-\mathrm{c}}$ means have different superscripts in the same column are significantly differed.

result are harmony with those of Quentin et al., (2004) who found that the reduction of the protein concentration growth, FCR and breast meat yield were significantly improved by Lys. supplementation up to $0.76 \%$ in the diet whatever the protein level.in the other hand, Abdel Maksoud et al., (2010) reported that birds fed the low-protein diets (21\%) supplemented with EAAs (21.68\% total CP)founded that birds fed the low-protein diets supplemented with EAAs showed significantly the highest BW and best FCR and FE. It was improved and BW increased significantly by increasing dietary lysine levels. the results reported the findings of present study are in agreement with there recorded increased in gain body weight of broilers with low CP diet with supplementation amino acids made by Roy., (2013).Abbasiet al., (2014),Ahmed., (2014) mention that,. dietary crude protein can be reduced by 1 unit in commercial broiler diets without compromising the bird performance and BWG, FI, and FCR did differ significantly between the various treatment groups. This low FI of birds from low protein group is contrary to report of Summers et al.(1988). The findings of present study Roy., (2013) who found found that, the body weight gain and feed conversion ratio of the broilers supplemented with 1.6 and $2.0 \%$ Thr. with 21 and $19 \% \mathrm{CP}$, respectively were significantly higher $(\mathrm{P}<0.01)$ than the other treatment, an experiment, FI was significantly higher in $1.6 \%$ threonine and $21 \% \mathrm{CP}$. Profitability per $\mathrm{kg}$ of broiler was significantly higher in the groups receiving $2.0 \%$ threonine and $19 \%$ threonine. It is obvious that the reduction in dietary $\mathrm{CP}$ level or the supplementation with limiting A.A. had no negative impact in FI compared with optimal dietary $\mathrm{CP}$ level. The result are harmony with those of Abdel Maksoud et al., (2010) found that birds fed the low-protein diets $(21 \%)$ supplemented with EAAs $(21.68 \%$ total CP) showed significantly the highest BW and best FCR and FE.Nukreaw and Bunchasak (2015) observed the 
significant difference in FCR in low crude protein diet with essential amino acid supplemented group than group of broilers receiving crude protein diet. Dozier et al., (2000a), Ciftci and Ceylan (2004), Ojediran T.K et al., (2017)results show that the birds fed diet $(16.6 \% \mathrm{CP}$ and $0.8 \%$ lysine) had a significantly $(\mathrm{p}<0.05)$ higher breast, Saki et al.,(2007) reported that decreased CP in the diet increased breast meat yield and reduction abdominal fat by these ratios of methionine/protein.

\section{Blood Plasma Constituents:}

Blood plasma metabolites concentrations as affected by dietary treatments are illustrated through different experimental periods are presented in Table (9).On one hand, Plasma total protein $(\mathrm{P}=0.034)$, albumin $(\mathrm{P}=0.002)$, and triglycerides $\quad(\mathrm{P}=0.002)$, were significantly affected by dietary treatments .On the other hand ,plasma globulin $(\mathrm{P}=0.385)$, Albumin / globulin ratio $(\mathrm{P}=0.867)$ and glucose $(\mathrm{P}=0.960)$ were not significantly affected by dietary treatment it is responsible that the diet with optimal dietary $\mathrm{CP}$ level and that with all supplemented A.A fortified low CP ,both showed the highest total protein concentrations, mean while, the broiler group with the contrl low CP diet showed the lowest plasma total protein values .Both immune systems are highly dependent upon an adequate availability of amino acids for the synthesis of these proteins and polypeptides, as well as other molecules with enormous biological importance (Kim et al., 2007). A sufficient intake of dietar methionine and cysteine is important for the synthesis of proteins of the immune system (Grimble., 2006).

Economical effieciency :Data listed in table (10) shows the economic efficiency (E.E.) for birds of different experimental groups as affected by treatments applied showed that higher relative cost / $\mathrm{Kg}$ gain and feed cost of producing $1 \mathrm{Kg}$ gain were reduced in amino acids supplemented groups compared to both of adequate protein or low protein diets was recorded by broiler chicks fed diet supplemented was all amino acids at(Trt.7) was 96.71 $\%$ followed by those that fed on diets supplemented with a level of amino acids (Trt 6), 97.42\% compared with (Trt.2), $113.59 \%$ with no supplemented amino acid we found high different with all groups which compared with control group which it was $100 \%$.

Table 10. Economical efficiency as affected by dietary protein levels and supplemental amino acids:

\begin{tabular}{|c|c|c|c|c|c|c|c|c|c|c|c|}
\hline \multirow[t]{2}{*}{ Trt. } & \multirow{2}{*}{$\begin{array}{l}\text { Total } \\
\text { LWG } \\
(\mathrm{g})\end{array}$} & \multirow{2}{*}{$\begin{array}{l}\text { Total } \\
\text { FI }(g)\end{array}$} & \multicolumn{4}{|c|}{ Feed cost/ group } & \multirow{2}{*}{$\begin{array}{l}\text { Price } / \mathrm{kg} \\
\text { feed } \\
\text { L.E. }\end{array}$} & \multirow{2}{*}{$\begin{array}{l}\text { Feed } \\
\text { cost } \\
\text { chick } \\
\text { L.E. }\end{array}$} & \multirow{2}{*}{\multicolumn{2}{|c|}{$\begin{array}{l}\text { Feed } \\
\text { cost / } \\
1 \mathrm{~kg} \mathrm{G} \\
\text { L.E. }\end{array}$}} & \multirow{2}{*}{$\begin{array}{l}\text { Relative } \\
\text { cost / Kg } \\
\text { gain } \%\end{array}$} \\
\hline & & & $\begin{array}{c}\text { Starter } \\
\text { L.E. }\end{array}$ & $\begin{array}{c}\text { Grower } \\
\text { L.E. }\end{array}$ & $\begin{array}{c}\text { Finisher } \\
\text { L.E. }\end{array}$ & $\begin{array}{l}\text { Total } \\
\text { L.E. }\end{array}$ & & & & & \\
\hline T1 & 1876 & 3309 & 46.67 & 207.2 & 218.73 & 472.6 & 3.75 & 13.13 & & 6.99 & 100 \\
\hline $\mathrm{T} 2$ & 1574 & 3336 & 43.41 & 198.7 & 206.65 & 448.8 & 3.56 & 12.5 & & 7.94 & 113.59 \\
\hline $\mathrm{T} 3$ & 1637 & 3251 & 43.81 & 192.1 & 205.13 & 441.1 & 3.5 & 12.25 & & 7.48 & 107.01 \\
\hline $\mathrm{T} 4$ & 1771 & 3499 & 44.23 & 192.9 & 202.65 & 440.0 & 3.49 & 12.22 & & 6.90 & 98.71 \\
\hline T5 & 1716 & 3286 & 44.23 & 193.1 & 205.43 & 442.7 & 3.51 & 12.27 & & 7.15 & 102.28 \\
\hline T6 & 1815 & 3384 & 44.31 & 192.9 & 208.00 & 445.2 & 3.53 & 12.36 & & 6.81 & 97.42 \\
\hline $\mathrm{T} 7$ & 1840 & 3251 & 44.79 & 194.8 & 208.22 & 447.8 & 3.55 & 12.44 & & 6.76 & 96.71 \\
\hline
\end{tabular}

T1: Positive control, T2: Neg. control,T3: Neg.+lysine,T4: Neg.+Lys+methionine,

T5:Neg.+Lys+Meth+Trep,T6:Neg.+Lys+Meth+Trep+Ther,T7:N.+Lys+Meth+Trep+Ther+Val

\section{References}

Abbasi, M. A.; Mahadavi, A.H.; Samie. A. H. and Jahanian, R. (2014). Effects of different levels of dietary crude protein and threonine on performance, humoral immune responses and intestinal morphology of broiler chicks. Brazilian J. Poult, Sci., 16 (1):34-35.

Abdel-Maksoud A., Yan F., Cerrate S., Coto C., Wang Z. and Waldroup P.W.(2010). Effect of dietary crude protein, lysine level and amino acid balance on performance of broilers 0 to 18 days of age Int. J. Poult. Sci. 9 (1): 21-27.

Ahmed, T. (2014). Effect of supplementation of Lthreonine on the performance of commercial broilers.M.Sci. Thesis. KVAFSU, Bidar,India.

Aletor, V.A., Hamid, I.I., Nieb, E. and Pfeffer, E. (2000). Low-protein amino acid supplemented diets in broiler chickens: effects on performance, carcass characteristics, whole-body composition and efficiencies of nutrient utilization. J. Sci. Food Agric. 80, 547-554.
Alleman.F and Leclercq.B. (2007). Effect of dietary protein and environmental temperature on growth performance and water consumption of male broiler chickens.Brit. Poult. Sci.8(11):607-610.

Bregendahl, K., Sell, J. I. and Zimmerman, D. R. (2002). Effect of low-protein diets on growth performance and body composition of broiler chicks.Poult. Sci., 81: 1156-1167

Ciftci, I. and Ceylan, N. (2004).Effects of dietary threonine and crude protein on growth performance, carcase and meat composition of broiler chickens. Brit. Poult. Sci., 45(2): 280-289.

Doumas B., Watson W., Biggs H. and Clinica C. A. (1971) Albumin standards and the measurement of serum albumin with bromcresol green.

Duncan,D.B. (1955).Multiple range and multiple F tests. Biometrics, 11: 1- 42

Dozier W. A. and Moran Jr .(2000a). Threonine requirement of broiler males from 42 to 56 days in a summer environment. J. App. Poult. Res.,9 : 496500 . 
Gornall A. G., Charles J. Bardawill, and Maxima M D. (1949). Determination of serum proteins by means of the biuret reaction.

Grimble RF (2006). The effects of sulfur amino acid intake onimmune function in humans. J Nutr 136, 1660S-1665S.

Kidd M.T. (2000). Nutritional considerations concerning threonine in broilers. Worlds Poult Sci., J.; 56:139-151.

Kim SW, Mateo RD, Yin YL \& Wu G (2007). Functional amino acids and fatty acids for enhancing production performance of sows and piglets. Asian-Aust J AnimSci 20, 295-306.

Koreleski, J. and Swiatkiewicz S. (2008). Effect of protein and methionine levels in a semi-organic diet for dual-purpose type chickens on slaughter performance and nitrogen balance .J. Anim. and Feed Sci.(17):381-391

Malveda, M. P., X. Man, S. Muller, and K. Yokose. 2006. Major amino acids. Chemical Economics Handbook Marketing Research Report. Menlo Park, CA: SRI Consulting, J. Anim. Sci. 87:937947 ... Science. 107:376-377.

Nukreaw, R. and Bunchasak, C. (2015).Effect of supplementing synthetic amino acids in lowprotein diet and subsequent re-feeding on growth performance, serum lipid profile and chemical body composition of broiler chickens.J.Poult. Sci. $52: 127-136$.

Ojediran, T.K. ,Oloruntade, T.O., Saka, D.R.O and Emiola, A. (2017) .Blood parameters, carcass yield, organ weight and villi morphometrics of broilers fed low protein diet in excess of dietary lysine.Trakia J. sci., ( 2): 121-127.
Quentin, M., Isabelle B., and Michel P. (2004).Effects of crude protein and lysine contents of the diet on growth and body composition of slow-growing commercial broilers from 42 to 77 days of age Anim. Res. 54 (2005) 113-122.

Roy, R. R. (2013). Effects of low protein threonine supplemented diet in the productivity and cost effectiveness of commercial broilers. M.S. (Poultry science) Thesis. Bangladesh Agricultural University, Mymensingh, Bangladesh.

Saki, A. A., Mohammad, P.H.A., Ahmdi A., and Akhzar M.T. (2007). Decreasing broiler crude protein requirement by methionine supplementation- Pakistan J. Biolog. Sci. 10 (5): 757-762.

SAS. (2001). Statistical Analysis System users guide: Statistics .SAS Institute Inc., Cary, USA

Summers J. D., Leeson S., and Spratt D. (1988). Yield and composition of edible meat from male broilers as influenced by dietary protein level and amino acid supplementation. Can. J. Anim. Sci. 68: 241-248.

Soloni and Felix G. (1971). Simplified manual micro method for determination of serum triglycerides, published june. Clinical Chemistry, 17(6): 529534.

Waguespack, A. M., Powell S., Bidner T.D., Payne R.L., and Southern L.L. (2009).Effect of incremental levels of L-lysine and determination of the limiting amino acids in low crude protein corn-soybean meal diets for broilers.Poult. Sci. 88:1216-1226.

Waldroup, P.W., Jiang Q. and Fritts C.A. (2005).Effects of supplementing broiler diets low in crude protein with essential and nonessential amino acids. Int. J. Poult. Sci., 4 (6): 425-431. 
تأثير إضافة الأحماض الأمينية المحدة للعلائق المنخفضة في البروتين الخام علي أداء كتاكيت دجاج اللحم

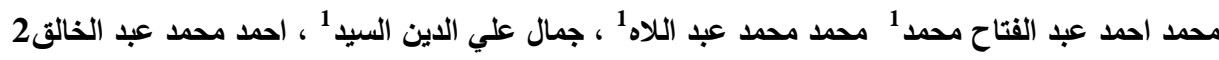

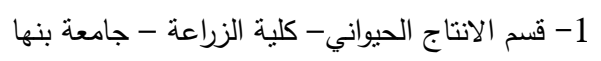

2 - قسم تغذية الدواجن - معهد بحوث الانتاج الحيواني - مركز البحوث الزراعية

أجريت هذه الدراسة لاراسة تأثير انخفاض مستوى البروتين الخام الغذائي مع استكماله بالأحماض الأمينية الأساسية علي أداء النمو ، الذبيحة

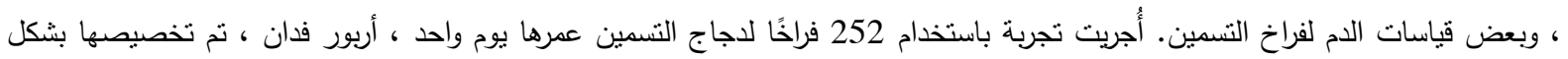

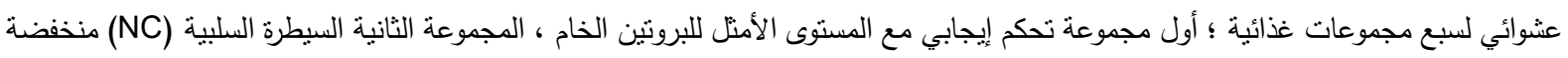

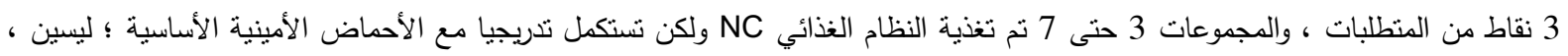
ليسين + ميثيونين ، ليسين + ميثيونين + تريبتوفان ، ليسين + ميثيونين + ترييتوفان + ثريونين و ليسين + ميثيونين + تريبتوفان + ثريونين + فالين

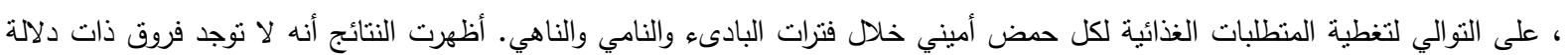

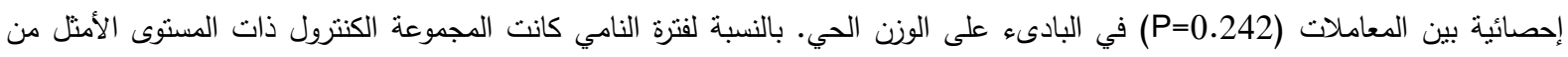

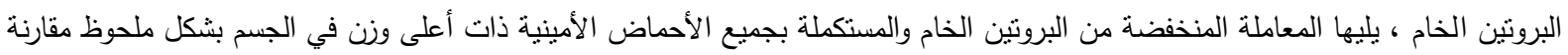

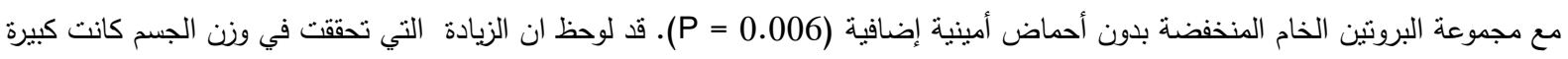

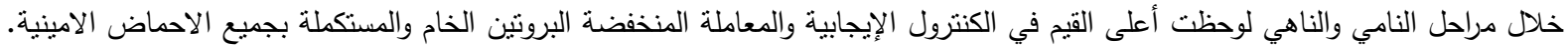

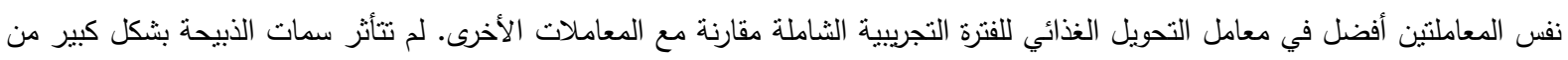

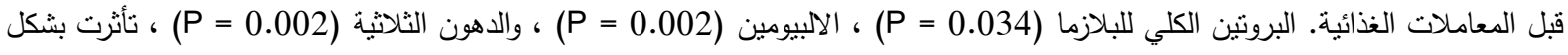

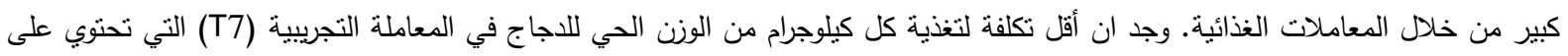
جميع الأحماض الأمينية المكملة للعلائق الغذائية منخفضة البروتين الخام يككن التوصية بخفض مستوى البروتين الخام في العلائق الغذائية لكتاكيت التسمين بنسبة 3 نقاط دون التأثير على أداء النمو عند إضافة الاحماض الأفية الامينية الأساسية. 